\title{
Vector identification, prevalence and anemia of bo- vine trypanosomosis in Yayo District, Illubabor Zone of Oromia Regional State, Ethiopia
}

\author{
Geremew Haile $^{1}$, Negesse Mekonnen ${ }^{1 *}$, Kumela Lelisa ${ }^{2}$ and Yitbarek Habtamu ${ }^{2}$ \\ ${ }^{1}$ Haramaya University, College of Veterinary Medicine, P. O. Box 138, Dire Dawa, Ethiopia \\ ${ }^{2}$ National Tsetse and Trypanosomosis Investigation and Control Center, Addis Ababa, Ethiopia \\ *Corresponding author: Haramaya University, College of Veterinary Medicine, P. O. Box 138, \\ Dire Dawa, Ethiopia, Email: mnegesse@yahoo.com \\ http://dx.doi.org/10.4314/evj.v20i1.3
}

\begin{abstract}
Trypanosomosis is one of the major impediments to livestock development and agricultural production in Ethiopia. It is cyclically transmitted by tsetse flies but also mechanically tsetse flies and by other biting flies. A cross-sectional study was conducted to identify the density and diversity of vectors and also the prevalence of bovine trypanosomosis from October, 2014 to May, 2015. The study was conducted in four selected settlement areas of the Yayo district in the Illubabor zone of Oromia Regional State, Ethiopia. Standard methods of sampling and identification were employed for both entomological and parasitological examination. Four species of the genus Glossina (Glossina morsitans submorsitans, Glossina pallidipes, Glossina tachinoides and Glossina fuscipes) and two genera of biting flies (Stomox$y s$ and Tabanus) were caught and identified. The overall apparent density of flies caught was 1095 (9.78 flies per trap per day), of which 410 (3.7 flies per trap per day) was Glossina species. Out of a total 488 cattle examined, 19 (3.9\%; 95\% CI: $2.36 \%-6.1 \%$ ) were found infected with trypanosomes. Three species were detected in the study area namely $T$. congolense $16(84.21 \%)$, T. vivax 2(10.53\%) and T. brucei $1(5.26 \%)$. The prevalence of trypanosomosis was not significantly affected by all risk factors considered ( $p>0.05)$. Trypanosomosis significantly affected the status of anemia or packed cell volume $(p<0.05)$. The mean PCV of parasitemic animals were significantly lower than that of aparasitemic ones $(\mathrm{P}<0.05)$. The prevalence of anemia was $19.67 \%$ (95\%CI: 16.24-23.48) and not significantly affected by the different risk factors considered $(\mathrm{P}>0.05)$ with the exception of Geri (Peasant association) which have shown the lowest anemia prevalence $(\mathrm{P}<0.05)$. The relative abundance of Glossina species caught and trypanosome detected confirmed the continuous challenge of the disease in the settlement areas. Therefore, the ongoing community based tsetse and trypanosomosis prevention/control strategy should be
\end{abstract}


strengthened in the area.

Keywords: Traps, Glossina, Packed cell volume, Trypanosoma, Buffy coat, Yayo district

\section{Introduction}

Tsetse transmitted animal trypanosomosis, also known as nagana, is one of the most significant and costly disease in the country where tsetse flies are highly distributed, hindering the effort being made for food self-sufficiency. Non-tsetse transmitted trypanosomosis also affects considerable number of animal populations in tsetse free zone of the country (STEP, 2012; Ayana Mekonnen et al., 2012; Birhanu Hadush et al., 2015). The disease mainly transmitted cyclically by the genus Glossina (tsetse flies), but also mechanically by biting flies, among which Tabanids and Stomoxy's are presumed to be the most important. The disease infects various species of mammals however, from an economic point of view, tsetse-transmitted trypanosomosis is particularly important in cattle (Mesele Taye et al., 2012).

Tsetse infests 10 million square kilometers between latitudes $14^{\circ} \mathrm{N}$ and $29^{\circ} \mathrm{S}$. Thirty eight African countries affected by the disease known as nagana (Radostits et al., 2007). In Ethiopia, about $240,000 \mathrm{~km}^{2}$ of land located in the Southern, South Western, Western and North Western parts is infested with tsetse flies and preclude farmers from rearing livestock (STEP, 2012). The most important trypanosome species affecting livestock in Ethiopia are T. congolense, T. vivax and T. brucei, in cattle, sheep and goat, T. evansi in camel and $T$. equiperdum in horse (Feyesa Regassa, 2004; Getachew Abebe, 2005).

The genus Glossina is blood sucking flies that belongs to the family Muscidae. Tsetse flies are found exclusively on the African continent and are closely related to the vegetation which protects them from solar radiation and wind. Based on the climate, vegetation and fauna characteristics of ecology to which they are found associated, tsetse flies are classified into three groups namely, savanna, riverine and forest types (Hippenheit et al., 2013). In Ethiopia, there are five species of Glossina and all are important vectors for African animal trypanososmosis (nagana). They are G. pallidipes, G.morsitanssubmorsitans, G. fuscipes, G. tachinoides and G. longipennis (Getachew Abebe, 2005).

Livestock in Yayo district play substantial role in the livelihood of the farmer as they are integral to the agricultural activities through provision of milk, meat, 
draught power and financial income through market. Unfortunately, livestock productivity is affected by different factors among which are diseases. One of these diseases is trypanosomosis which commonly occurred in association with Glossina and other mechanical vectors (YWAO, 2012). The area is known for its livestock and agricultural production potential. However it is found within the tsetse belt and trypanosomosis impedes the livestock and agricultural productivity. During the past decade, different prevention and control measures were implemented in order to reduce the impact of trypanosomosis in the area by National tsetse and trypanosomosis investigation and control center (NTTICC) in collaboration with Yayo woreda agricultural office, however, trypanosomosis is still considered as an important disease in the district. Therefore, the main objectives of the present study were to identify the responsible vectors and estimate the prevalence of bovine trypanosomosis in Yayo district of Illubabor zone, Oromia Regional State.

\section{Materials and Methods}

\section{Study area}

The study was conducted in Yayo district, which is located in Illubabor zone of Oromia Regional States, South Western Ethiopia (Figure 1). It is located about 564 kilometers West of Addis Ababa, and 36 kilometers from Metu. Geographically, Yayo town falls between $8^{\circ}$ to $26^{\circ} 8^{\prime \prime} \mathrm{N}$ latitudes and $36^{\circ}$ to $20^{\circ} 97^{\prime \prime} \mathrm{E}$ longitudes. The four peasant associations namely, Wutate, Geri, Wabo and Bondawo are settlement areas. The total land area covers 84,626 hectare with an altitudes of 1400 to 2010 meter above sea level. The annual mean temperature ranges from $18^{\circ} \mathrm{C}$ to $27^{\circ} \mathrm{C}$ and receives annual rainfall greater than $1400 \mathrm{~mm}$. The human population of the district is 57,938. The livestock populations of the district were estimated to be 60,202 cattle, 30,120 sheep, 35,120 goats, 38,386 poultry, 4,693 horses and 5232 donkeys. The farming system of the area was mixed farming where $87 \%$ of the total population engaged in agriculture. Crop and livestock sales are important source of income for all wealth groups (CSA, 2011; YWAO, 2012). 


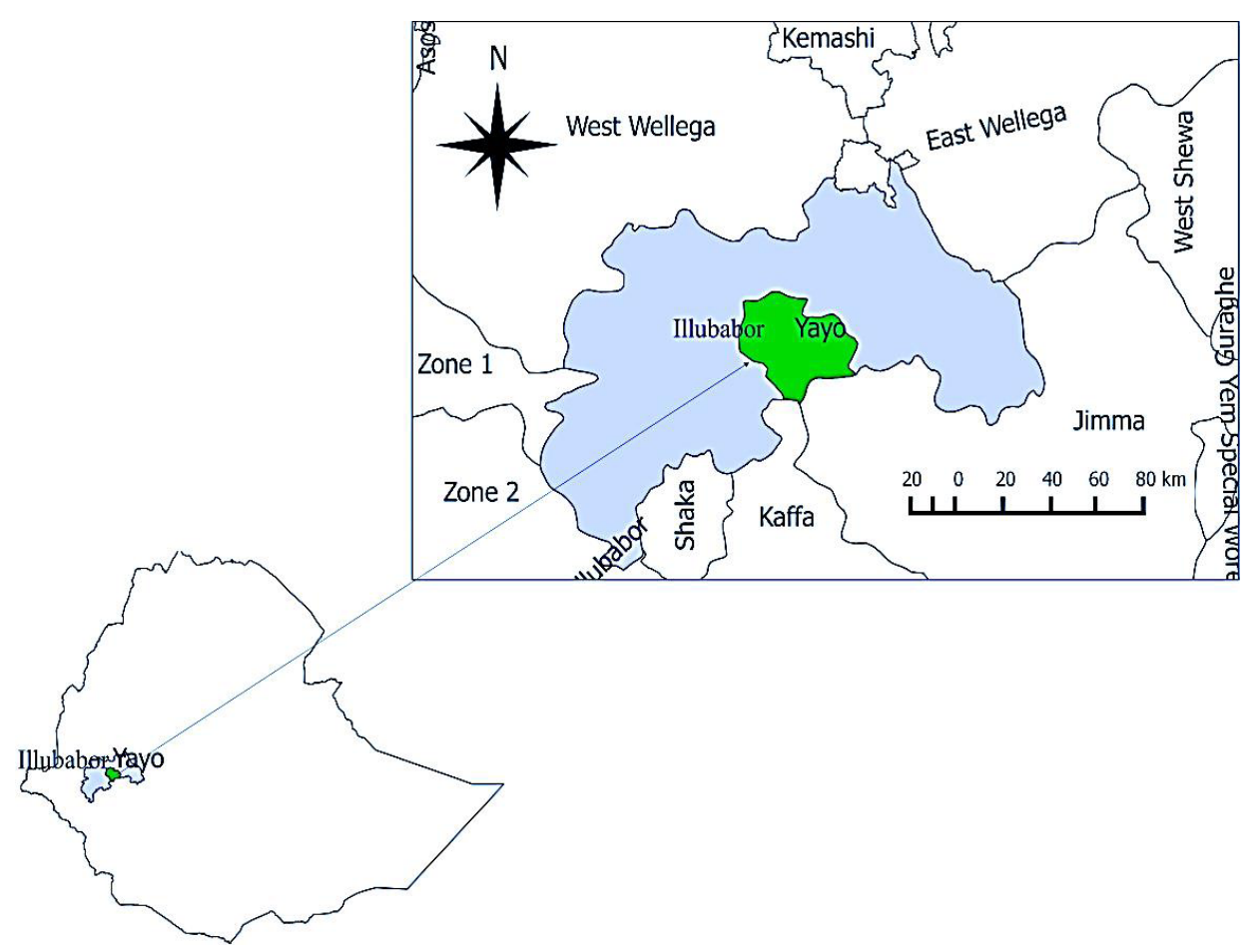

Figure 1: Map of the study area

\section{Study animals and sample size}

The study was conducted on local breed cattle from four peasant associations (PAs). The body condition score were classified as poor, medium and good by observing the body condition of the animals in the field (Nicholson and Butterworth, 1996). The ages of animals were also estimated by the dentition method (Gatenby, 1991) and from owner information. The number of animals required for the study was determined using the formula given by Thrusfield (2005) for multi-stage sampling, by using $95 \%$ level of confidence, $50 \%$ expected prevalence and 0.05 desired absolute precision. Thus, 384 cattle were needed for the study. However, to increase the precision 488 were included.

\section{Study design}

A cross-sectional study was used to estimate the current prevalence of bovine 
trypanosomosis and vectors in the study area from November, 2014 to June, 2015. The PA's were selected based on their accessibility to transport and information from the district's administrative body. Multistage sampling was used to sample animals, where, herds were selected from each PA's by simple random sampling as primary sampling units. From the selected herds, individual animals to be sampled were selected by simple random sampling techniques as secondary sampling units.

\section{Study methodology}

\section{Entomological survey}

A total of 56 monoconical traps were deployed in four peasant association of the district (16 in Wutate, 13 in Geri, 13 in Bondawo and 14 in Wabo) at approximate interval of $200-250 \mathrm{~m}$. All traps were baited with acetone, octenol (1-3 octenol) and cow urine filled in separate bottles. After 48 hours of deployment, tsetse flies in the cages were counted and identified based on their habitat and morphology to the genus and species level. Other biting flies were also identified according to their morphological structures such as size and proboscis at the genus level (Uilenberg, 1998; Pollock, 1982). Tsetse flies were sexed just by observing the posterior end of the ventral aspect of the abdomen using hand lens. Male flies were identified by their enlarged hypopygium in the posterior ventral end of the abdomen. The apparent density of the tsetse fly was calculated as the number of tsetse catch/trap/day (STEP, 2012).

\section{Survey of trypanosomosis}

Blood samples were collected randomly from cattle of the settlement into capillary tube after piercing the ear vein by using a lancet. One end of the capillary tube was sealed and centrifuged at 12,000rpm for 5 minutes to separate the blood cells and to concentrate trypanosomes using centrifugal forces as buffy coat. Then PCV was measured using haematocrit reader. The capillary tubes were broken just $1 \mathrm{~mm}$ below buffy coat and expressed on microscopic slide, mixed and covered with $22 \times 22 \mathrm{~mm}$ cover slip. Then it was examined under $40 \mathrm{x}$ objective of a microscope using dark ground buffy coat technique to detect the presence of the parasite (Murray et al., 1977). Buffy coat positive samples were stained by Giemsa's in thin blood smears, fixed with methanol for 5 minute and examined under oil immersion using $100 \mathrm{x}$ objectives to identify the species of trypanosomes. 


\section{Data analysis}

Data obtained were stored in Microsoft Excel spreadsheet. The data were summarized and presented in tables and analyzed by using STATA version 11.0 for Windows (Stata Corp. College Station, TX).The density of fly population was calculated by dividing the number of flies caught by the number of traps deployed and number of days of deployment and expressed as Fly/Trap/Day (F/T/D), (Pollock, 1982).The association between trypanosome infection and risk factors or variables (age, sex, body condition and origin/peasant association) were determined by univariable logistic regression. Two sample student t-tests were used to compare mean PCV of study animals. A statistically significant difference between variables exists when $p<0.05$ at $95 \%$ confidence level (CI). The origin of the animals was categorized in to four peasant associations, body condition score was categorized in three (poor, medium and good). The age of animals was categorized into two; less than or equal to one year are calf raised near the homestead and assumed to have less frequent contact with the vectors and greater than one year are adult animals raised far from home and went for grazing and watering in the grassland, bush and river side's which might get frequent contact with the vector. PCV value was analyzed in two ways as categorical and continuous variables. PCV was categorized as anemic if it is less than $24 \%$ and normal if it is greater than or equal to $24 \%$.

\section{Results}

\section{Entomological results}

Four species of Glossina (G. morsitans submorsitans, G.pallidipes, G. tachinoides and G.fuscipes) and two genera of biting flies (Stomoxys and Tabanus) were identified during the entomological survey. The relative abundance of Glossina species and other biting flies (Table 1). The overall Glossina species caught per 48 hours with sex proportion in different peasant associations (PA's) (Table 2). 
Table 1: Relative abundance of Glossina and other biting flies in study areas

\begin{tabular}{lcccccccccc}
\hline PA's & $\begin{array}{c}\text { No of } \\
\text { traps }\end{array}$ & $\begin{array}{c}\text { Over } \\
\text { all } \\
\text { flies }\end{array}$ & \multicolumn{1}{c}{ Glossina species } & \multicolumn{3}{l}{ Other biting flies } \\
& & & Gm & Gp & Gt & Gf & (F/T/D) & Stomoxy & Tabanus & (F/T/D) \\
\hline Wutate & 16 & 538 & 54 & 0 & 0 & 0 & 1.69 & 484 & 0 & \\
Geri & 13 & 336 & 1 & 0 & 151 & 10 & 6.23 & 174 & 0 & \\
Wabo & 13 & 175 & 41 & 9 & 24 & 91 & 6.35 & 10 & 0 & \\
Bondawo & 14 & 46 & 21 & 0 & 8 & 0 & 1.04 & 15 & 2 & 2.1 \\
Total & 56 & 1095 & 117 & 9 & 183 & 101 & 3.7 & 683 & 2 & \\
Gm= Glossina morsitans submoritans, Gp= Glossina pallidipes, Gt= Glossina tachinoides and Gf= Glossina \\
fuscipes, PA's= peasant associations, F/T/D=fly/trap/day
\end{tabular}

Table 2: Proportion of male and female Glossina species in the study area

\begin{tabular}{lccc}
\hline PA's & $\begin{array}{c}\text { Total } \\
\text { number of } \\
\text { Glossina }\end{array}$ & Male & Female \\
\cline { 3 - 4 } & 54 & $21(39)$ & Number (\%) \\
\hline Wutate & 162 & $77(47)$ & $33(61)$ \\
Geri & 165 & $74(45)$ & $85(52.5)$ \\
Wabo & 29 & $11(23)$ & $91(55)$ \\
Bondawo & 410 & $183(44.6)$ & $18(77)$ \\
Total & & & $227(55.4)$ \\
\hline PA's= peasant associations & &
\end{tabular}

\section{Parasitological results}

Out of 488 cattle examined, the prevalence of Trypanosome infection in the area was $3.9 \%$ (95\% CI=2.36\%-6.01\%). The association between infection and study variables (Table 3). Of the 19 cattle positive for trypanosomes, 16 (84.2\%), 2 (10.5\%) and 1 (5.3\%) cases were caused by T. congolense, T. vivax and T. brucei, respectively. High infection of trypanosome was recorded in Wutate, followed by Geri, Bondawo and Wabo. The infection was also high in cattle with poor body condition (5.6\%) and age less than or equal to 1 years (4.2\%) and slightly higher in males than females. However, there was no significant variation seen in the infection status within categories $(\mathrm{P}>0.05)$.

\section{Hematological findings}

The mean PCV of anemic $(20.81 \% \pm 0.18 \mathrm{SE})$ and normal $(28.83 \% \pm 0.18 \mathrm{SE})$ cattle showed significant difference $(P<0.05)$. The proportion of anemic animals infected with the parasite were significant $(P<0.05)$ as compared with non- 
anemic positive animals (Table 4). The risk of being anemic increased by 7.86 $(\mathrm{CI}=3.00-20.55)$ folds when animals were infected with trypanosome $(P<0.05)$. Moreover, linear regression analysis indicated that a unit variation or increase of the buffy coat result leads to a reduction in the PCV by $4.7 \%(P<0.05)$ (Table $5)$.

Packed cell volume of parasitemic animals fall in the range of $17-36 \%$, while in aparasitemic cattle the PCV was in the range of $15-41 \%$. The overall mean PCV in the examined animals was $27.25+0.21 \mathrm{SE}$. The mean PCV of parasitemic animals were significantly lower than that of aparasitemic ones $(\mathrm{P}<0.05)$ table 7. Among 469 non parasitized animals, 17.9\% had PCV $<24$ and from the 19 parasitized animals $12(63.16 \%)$ had $\mathrm{PCV}<24$. The prevalence of parasitemic and anemic animals $(63.16 \%)$ were significantly higher as compared to the parasitemic and nonanemic $36.84 \%(\mathrm{P}<0.05)$.

From the total of 488 cattle examined 96 (19.67\%) were anemic with $95 \%$ CI (16.24-23.48) (Table 6). Among these anemic animals, 12.5\% were positive for trypanosomosis while only $1.8 \%$ of non-anemic animals were positive for trypanosomosis (Table 4). On the other hand, $87.5 \%$ of anemic cattle were negative for trypanosomosis. The prevalence of anemia was significantly lower in Geri than other peasant associations $(\mathrm{P}<0.05)$. All other risk factors (body condition, age and sex) were not statistically significant (Table 6). 
Table 3: Univariable logistic regression analysis of peasant association, body condition, age and sex with buffy coat result

\begin{tabular}{|c|c|c|c|c|c|c|}
\hline $\begin{array}{l}\text { Risk } \\
\text { factors }\end{array}$ & $\begin{array}{l}\text { Risk } \\
\text { category }\end{array}$ & $\begin{array}{c}\text { Number } \\
\text { Examined }\end{array}$ & $\begin{array}{l}\text { Number } \\
\text { Positive }\end{array}$ & $\begin{array}{c}\text { Prevalence } \\
(95 \% \text { CI })\end{array}$ & $\begin{array}{c}\text { OR } \\
(95 \% \mathrm{CI})\end{array}$ & $P$-value \\
\hline \multirow{4}{*}{$\begin{array}{l}\text { Origin of } \\
\text { animals } \\
\text { (PA's) }\end{array}$} & Wutate & 147 & 9 & $6.1(2.22-10.02)$ & Reference & - \\
\hline & Geri & 148 & 5 & $3.4(0.45-6.31)$ & $1.86(0.61-5.70)$ & 0.27 \\
\hline & Wabo & 120 & 1 & $0.8(-0.83-2.47)$ & $7.78(0.97-62.15)$ & 0.05 \\
\hline & Bondawo & 73 & 4 & $5.5(0.21-10.75)$ & $1.13(0.33-3.78)$ & 0.84 \\
\hline \multirow[t]{3}{*}{$\mathrm{BCS}$} & Poor & 89 & 5 & $5.6(0.79-10.44)$ & reference & - \\
\hline & Medium & 212 & 6 & $2.8(0.59-5.07)$ & $2.04(0.61-6.88)$ & 0.25 \\
\hline & Good & 187 & 8 & $4.3(1.36-7.19)$ & $1.33(0.42-4.19)$ & 0.62 \\
\hline \multirow[t]{2}{*}{ Age } & $<=1$ year & 96 & 4 & $4.2(0.14-8.19)$ & $1.09(0.35-3.37)$ & 0.87 \\
\hline & $>1$ year & 392 & 15 & $3.8(1.92-5.73)$ & & \\
\hline \multirow[t]{2}{*}{ Sex } & Female & 258 & 9 & $3.5(1.24-5.74)$ & $1.26(0.50-3.15)$ & 0.63 \\
\hline & Male & 230 & 10 & $4.4(1.69-6.99)$ & & \\
\hline
\end{tabular}

Table 4: Univariable logistic regression analysis of anemic and normal cattle's

\begin{tabular}{|c|c|c|c|c|c|c|}
\hline Category & $\begin{array}{c}\text { Number } \\
\text { of } \\
\text { animals } \\
\text { examined }\end{array}$ & $\begin{array}{l}\text { Number } \\
\text { Positive }\end{array}$ & $\begin{array}{l}\text { Proportion } \\
\text { (95\% CI) }\end{array}$ & $\begin{array}{c}\text { Mean } \\
\text { PCV } \pm \text { SE }\end{array}$ & $\begin{array}{l}\text { OR }(95 \% \\
\text { CI })\end{array}$ & P-value \\
\hline Anemic $(<24)$ & $96(19.67)$ & 12 & $\begin{array}{c}12.5 \%(5.83- \\
19.17)\end{array}$ & $20.81 \pm 0.18$ & $\begin{array}{c}\text { 7.86(3.00- } \\
20.55)\end{array}$ & 0.00 \\
\hline Normal ( $\geq 24)$ & $392(80.33)$ & 7 & $1.8 \%(0.47-3.10)$ & $28.83 \pm 0.18$ & & \\
\hline Total & $488(100 \%)$ & 19 & $3.9 \%(2.36-6.01)$ & $27.25+0.21$ & & \\
\hline
\end{tabular}

Table 5: Linear regression analysis of PCV and buffy coat result

\begin{tabular}{lcccc}
\hline PCV & Coefficient & $\begin{array}{c}\text { Standard } \\
\text { error }\end{array}$ & $\boldsymbol{P}$-value & 95\% CI \\
\hline Buffy coat result & -4.70 & 1.05 & 0.00 & $-6.76-(-2.64)$ \\
Constant & 27.44 & 0.21 & 0.00 & $27.03-27.84$ \\
\hline CI=confidence interval & &
\end{tabular}


Geremew Haile et al.,

Table 6: Univariable logistic regression analysis of risk factors with the prevalence of anemia

\begin{tabular}{|c|c|c|c|c|c|c|}
\hline $\begin{array}{l}\text { Risk } \\
\text { factors }\end{array}$ & $\begin{array}{c}\text { Risk } \\
\text { category }\end{array}$ & $\begin{array}{l}\text { Number } \\
\text { Examined }\end{array}$ & $\begin{array}{l}\mathrm{PCV}<24 \\
\text { (anemic) }\end{array}$ & $\begin{array}{c}\text { Prevalence of } \\
\text { anemia }(95 \% \mathrm{CI})\end{array}$ & $\begin{array}{c}\text { OR } \\
(95 \% \mathrm{CI})\end{array}$ & $P$-value \\
\hline $\begin{array}{l}\text { Origin } \\
\text { of } \\
\text { animals } \\
\text { (PA's) }\end{array}$ & $\begin{array}{l}\text { Wutate } \\
\text { Geri } \\
\text { Wabo } \\
\text { Bondawo }\end{array}$ & $\begin{array}{c}147 \\
148 \\
120 \\
73\end{array}$ & $\begin{array}{l}42 \\
12 \\
24 \\
18\end{array}$ & $\begin{aligned} 28.57 & (21.22-35.92) \\
8.11 & (3.68-12.53) \\
20.00 & (12.79-27.20) \\
24.66 & (14.68-34.64)\end{aligned}$ & $\begin{array}{c}\text { Reference } \\
4.53(2.27-9.04) \\
1.60(0.90-2.84) \\
1.22(0.64-2.23)\end{array}$ & $\begin{array}{c}- \\
0.00 \\
0.11 \\
0.54\end{array}$ \\
\hline BCS & $\begin{array}{l}\text { Poor } \\
\text { Medium } \\
\text { Good }\end{array}$ & $\begin{array}{c}89 \\
212 \\
187\end{array}$ & $\begin{array}{l}20 \\
49 \\
27\end{array}$ & $\begin{array}{c}22.47(13.73-31.21) \\
23.11(17.41-28.81) \\
14.43(9.37-19.50)\end{array}$ & $\begin{array}{c}\text { Reference } \\
1.04(0.57-1.87) \\
1.72(0.90-3.27)\end{array}$ & $\begin{array}{c}- \\
0.90 \\
0.09\end{array}$ \\
\hline Age & $\begin{array}{l}<=1 \text { year } \\
>1 \text { year }\end{array}$ & $\begin{array}{c}96 \\
392\end{array}$ & $\begin{array}{l}14 \\
82\end{array}$ & $\begin{array}{c}14.58(7.47-21.70) \\
20.92(16.88-24.96)\end{array}$ & $1.54(0.84-2.87)$ & 0.16 \\
\hline Sex & $\begin{array}{l}\text { Female } \\
\text { Male }\end{array}$ & $\begin{array}{l}258 \\
230\end{array}$ & $\begin{array}{l}48 \\
48\end{array}$ & $\begin{array}{l}18.60(13.83-23.37) \\
20.87(15.59-26.15)\end{array}$ & $1.15(0.74-1.80)$ & 0.53 \\
\hline
\end{tabular}

$\overline{\mathrm{OR}=\text { odds ratio }}$

Table 7: Mean PCV value of parasitemic and parasitemic animals

\begin{tabular}{lcccccc}
\hline $\begin{array}{l}\text { Infection } \\
\text { status }\end{array}$ & No examined & Mean PCV & 95\%CI & SEM & t-test & p-value \\
\hline Parasitemic & 19 & 22.74 & $20.00-25.47$ & 0.20 & 4.48 & 0.00 \\
Aparasitemic & 469 & 27.44 & $27.04-27.84$ & 1.30 & & \\
Total/average & 488 & 27.25 & $26.85-27.66$ & 0.21 & & \\
\hline PCV= packed cell volume, CI= confidence interval, SEM=standard error of the mean & &
\end{tabular}

$\mathrm{PCV}=$ packed cell volume, $\mathrm{CI}=$ confidence interval, $\mathrm{SEM}=$ standard error of the mean 


\section{Discussion}

In this study, the entomological survey revealed that four species of Glossina (G. morsitans submorsitans, G. pallidipes, G. tachinoidesand G. fuscipes) andtwo genera of biting flies (Stomoxys and Tabanus species) were detected in the selected settlement areas of the Yayo district. The most abundant species were G. tachinoides followed by G. fuscipes, G. morsitans submorsitans and G. pallidipes.The four species of Glossina have also been reported in the Western and South Western parts of the country (Terzu Daya and Getachew Abebe, 2008; Kumela Lelisa et al., 2015). The overall apparent density of Glossina species was 3.7 flies per trap per day. The apparent densities of Glossina species were 6.35, 6.23, 1.69 and 1.04 flies per trap per day in Wabo, Geri, Wutate and Bondawo, respectively.

In the Western part of the country, various reports indicated that the apparent density of Glossina species ranges from 0.3 to 24.4 flies per trap per day (Mulugeta Desta et al., 2013; Kumela Lelisa et al., 2014). This wider range might be due to differences in the density of vegetation cover and favorable climate. According to Leak (1999), vegetation is vital for providing suitable conditions; the savanna, forest and riverine tsetse flies concentrate in the wooden savanna, in the bush vegetation and near the edge of river, where the vegetation is dense, respectively (Jordan, 1993). A higher number of female tsetse species 227(55.4\%) were caught than male 183(44.6\%), which is in line with various reports from the country (Terzu Daya and Getachew Abebe, 2008; Kumela Lelisa et al., 2014; Kumela Lelisa et al., 2015). This could be attributed to the longer lifespan of female compared to male Glossina (Leak, 1999).

The prevalence of bovine trypanosomosis in Yayo district was 3.9\% (95\% CI 2.36-6.01). The current finding was lower than the reports in Southern Ethiopia $14.2 \%$ by Feyissa Begna et al. (2011) and $27.5 \%$ by Abraham Zecharias and Tesfaheywet Zeryehun (2012) and in western Ethiopia 10.8\% by Kumela Lelisa et al. (2014). This is because of the implementation of different prevention and control measures in the area such as the use of trypanocidal drugs in the form of prophylactic/treatment and the implementation of community based vector control measures (using traps and insecticide impregnated targets). The finding was in agreement with the report from Didesa District of Oromia Regional State with $4.86 \%$ prevalence (Gamechu Feyissa et al., 2015), Arbaminch District, southern Ethiopia with $4.43 \%$ prevalence (Wondewosen Teka et al., 2012),

Ethiop. Vet. J., 2016, 20 (1), 39-54 
and Metekel zone of Benishangul Gumuz regional sate with 5.43\%prevalence (Kumela Lelisa et al., 2015).

The current study confirmed that the occurrence of trypanosome infections in cattle is clearly linked to the presence of potential fly vectors (Glossina species and other biting flies). In this study three species of trypanosomes were identified, namely T. congolense (84.2\%), T. vivax (10.5\%) and T. brucei (5.3\%). These species were widespread in most parts of Western and South Western Ethiopia (Getachew Abebe, 2005; Shemelis Mulaw et al., 2011; Mulugeta Desta et al., 2013; Kumela Lelisa et al., 2014). Trypanosoma congolense was found to be the most prevalent compared to other species. This was in line with various reports from the Western and Southern parts of the country (Jemere Bekele et al., 2010; Abraham Zecharias and Tesfaheywet Zeryehun, 2012; Wondewosen Teka et al., 2012; Mulugeta Desta et al., 2013).

Univariable logistic regression analysis of the different risk factors (origin/ peasant association, body condition score, age and sex) considered during the study did not show any significant association with occurrence of trypanosomosis. On the other hand, the risks of being anemic increased by 7.86 times (Table 4 ) when cattle are infected trypanosomes $(\mathrm{P}<0.05)$. Moreover, linear regression analysis of $\mathrm{PCV}$ and parasitemic cattle also confirmed a unit variation/increase in the buffy coat result caused a reduction of the PCV value by $4.7 \%,(\mathrm{P}<0.05)$ (Table 5). Among anemic cattle $12.5 \%$ were diseased with trypanosomosis. The current finding is consistent with the reports from western Wollega zone, Oromia regional state (Senbeta Tasew and Reta Duguma, 2012). However, the current finding was higher than the reports from Western Gojjam, Amhara region (Ayana Mekonnen and Tesfahywot Zeryehun, 2012).

In this study the overall prevalence of anemia was $19.67 \%$ which was lower than the reports of Senbeta Tasew and Reta Duguma (2012) and Ayana Mekonnen and Tesfahywot Zeryehun 2012). This might be due to concurrent diseases that can cause anemia. Similarly, the overall mean PCV (27.25 \pm 0.21$)$, the anemic $(20.81 \pm 0.18)$ and non-anemic $(28.83 \pm 0.18)$ mean PCV of cattle are consistent with the finding of Senbeta Tasew and Reta Duguma (2012). From the risk factors considered during the study animals which came from Geri (PA's) have shown the lowest anemia prevalence $(\mathrm{P}<0.05)$. All other risk factors (body condition, age and sex) did not show any significant difference $(\mathrm{P}>0.05)$. 
The mean PCV of parasitemic cattle were significantly lower than that of the aparasitemic ones $(\mathrm{P}<0.05)$ (Table 7). Similar findings were reported by Abraham Zecharias and Tesfaheywet Zeryehun (2012) and Ayana Mekonnen et al. (2012). Packed cell volume has been demonstrated to be a good indicator of trypanosomal infection (Marcotty et al, 2008). The aparasitemic cattle with $\mathrm{PCV}<24 \%$ in the current study could be either due to the low sensitivity of buffy coat techniques in chronic cases of trypanosomosis or it might be due to other factors like poor nutrition and other diseases particularly parasitic diseases which cause anemia (Picozzi et al., 2002).

\section{Conclusion}

The results of the current study identified four species of Glossina and other biting flies that serve as potential vectors for the transmission of trypanosomes. Glossina morsitans submorsitans, G. pallidipes, G. tachinoides and G. fuscipes were the common species of Glossina identified. Similarly, T. congolense, T. vivax and T. brucei were the species of trypanosome detected in the area. The relative abundance of Glossina species caught and the prevalence of trypanosomosis investigated in the area confirmed the continuous challenge of trypanosomosis in the area. Packed cell volume alone could not be used as a tool for the diagnose trypanosomosis, because only small proportion (12.5\%) of anemic animals were positive to trypanosome. Considering the above facts, the ongoing tsetse and trypanosomosis prevention and control strategy should be strengthened in the area.

\section{Acknowledgements}

We are very much grateful to Haramaya University, College of Veterinary Medicine and all staff of Bedele National Tsetse and Trypanosomosis Investigation and Control Centre (NTTICC). We appreciated for their valuable advice, encouragements, provision of materials, devotion of time and co-operation in different aspects for the success of this work. Finally, I would extend my sincere gratitude to Dr. Birhanu Sibhat for his constructive comments.

\section{References}

Abebe, G., 2005. Trypanosomosis in Ethiopia. Ethiop, J. Bio. Sci., 4(1), 75 -121. 
Begna, F., Samson, A. and Mihreteab, B., 2011. Bovine trypanosomosis in selected villages of Humbo District, Southern Ethiopia, Global Vet., 7 (2), 192-198.

Bekele, J., Asmare, K., Abebe, G., Ayelet, G. and Gelaye, E., 2010. Evaluation of deltamethrin applications in the control of tsetse and trypanosomosis in the southern rift valley areas of Ethiopia, Vet. Parasitol., 168, 177-184.

CSA, 2011. Central Statistic Authority: Federal Democratic Republic of Ethiopia, Agricultural sample enumeration statistical abstract.

Daya, T. and Abebe, G., 2008. Seasonal dynamics of tsetse and trypanosomosis in selected sites of Ethiopia. Ethiop. Vet. J., 12, 77-98.

Desta, M., Menkir, S. and Kebede, A., 2013. The study on tsetse fly (Glossina species) and their role in the trypanosome infection rate in Birbir Valley, Baro-Akobo river system, western Ethiopia. J. Vet. Med. Anim. Health., 5(7), 186-194.

Feyissa, G., Aynalem, M., Birhanu, H., Gemechu, C. and Gezahegn, A., 2015. Epidemiological status and vector identification of bovine trypanosomiosis in Didesa District of Oromia Regional State, Ethiopia. Int. J. Nutr. Food Sci., 4(3), 373-380.

Gatenby, R., 1991. The Tropical Agriculture, London and Beging Stock Mc Millan Education Ltd. ACCT. Pp. 6-10.

Hadush, B., Regassa, F., Mussa, S., Weldu, K., Tadesse, G., Ashenafi, H., Tola, A., Tesfaye, D., Dirk, B., Bruno, M. G. and Philippe, B., 2015. Epidemiology of Trypanosoma evansi and Trypanosoma vivax in domestic animals from selected districts of Tigray and Afar regions, Northern Ethiopia. Parasite vector., 8, 212.

Hippenheit, A., Murugaiyan, J., Bauer, B., Steuber, S., Clausen, P.H. and Roester, U., 2013. Identification of Tsetse (Glossina Spps), Plos. Negl. Trop. Dis., 7(7), Pp.2305.

Jordan, A.M., 1993. Tsetse flies (Glossinidae) in medical insects and arachnids. Chapman and Hall, London, 333-338.

Leak, S.G.A., 1999. Tsetse biology and ecology: Their role in the epidemiology and control of trypanosomosis, CAB International, Wallingford, UK.

Lelisa, K., Damena, D., Kedir, M. and Feyera, T., 2015. Prevalence of bovine trypanosomosis and apparent density of tsetse and other biting flies in Mandura District, Northwest Ethiopia. J. Vet. Sci. Technol., 6, 3.

Lelisa, K., Shimeles, S., Bekele, J. and Sheferaw, D., 2014. Bovine trypanosomosis and its fly vectors in three selected settlement areas of Hawa- Gelan district, Western Ethiopia, Onderstepoort. J. Vet., 81(1), 5-10.

Marcotty, T., Simukoko, H., Berkvens, D., Vercruysse, J., Praet, N and Van den Bossche, P., 2008. Evaluating the use of packed cell volume as an indicator of trypanosomal infections in cattle in eastern Zambia, Prev. Vet. Med., 87, 288-300. 
Mekonnen, A., Tesfaheywet, Z and Getnet, F., 2012. A cross-sectional study on the prevalence of bovine trypanosomosis in Amhara region, Northwest Ethiopia. Livest. Res. Rural Dev., 24(8).

Mulaw, S., Addis, M. and Fromisa, A., 2011. Study on the prevalence of major trypanosome affecting bovine on tsetse infested, Asosa district of Benshagul-Gumuz Regional State, Western Ethiopia, Global Vet., 7(4), 330-336.

Mulugeta D., Menkir, S. and Kebede, A., 2013. Prevalence and seasonal incidence of bovine trypanosomosis in Birbir valley, Baro-Akobo river system, Western Ethiopia, J. Vet. Med. Anim. Health., 5(5), 138-143.

Murray, M. Murray, P. K. and Mcintyre, W. I. M., 1977. An approved parasitological technique for the diagnosis of African animal trypanosomosis. Trans. R. Soc. Trop. Med. Hyg., 71, 325-326.

Nicholson, M. and Butterworth, T., 1996. A guide to body condition score in zebu cattle international livestock center for Africa, Addis Ababa, Ethiopia.

Picozzi, K., Tilly, A., Fevre, E. M., Coleman, P., Magona, J. W., Odiit, M., Eisler, M.C. and Welbum, S., 2002. The diagnosis of trypanosome infections: applications of novel technology for reducing disease risk, Afr. J. Biotechnol., 1, 39-45.

Pollock, J.N., 1982. Training manual for tsetse control personnel, Volume 2, FAO, Rome.

Radostits, O.M., Gay, C.C., Hinchcliff, K.W. and Constable, P.D., 2007. Veterinary medicine. A text book of the disease of cattle, horse, sheep, pigs and goats, $10^{\text {th }}$ edition. By Saunders Elsevier, Edinburgh. Pp. 1534.

Regassa, F. and Abebe, G., 2004. Current epidemiological situation of bovine trypanosomosis in Limu Shay tsetse controlled area of upper Didessa Valley. Ethiop. Vet. J., 13 (2), 19-33.

STEP, 2012. Ministry of Science and Technology. Southern tsetse eradication project (step). Field operation manual of tsetse and trypanosomosis control and monitoring, Addis Ababa, Ethiopia, Pp. 5-63

Tasew, S. and Duguma, R., 2012. Cattle anaemia and trypanosomosis in western Oromia State, Ethiopia. Revue. Med. Vet., 163(12), 581-588.

Taye, M., Belihu, K., Bekana, M. and Sheferaw, D., 2012. Assessment of impacts of tsetse and trypanosomosis control measures on cattle herds composition and performance in Southern region, Ethiopia, Trop. Anim. Hlth. Prod., 44, 1759-1763.

Teka, W., Dechasa, T. and Anteneh, W., 2012. Prevalence study of bovine trypanosomosis and tsetse density in selected villages of Arbaminch, Ethiopia. J. Vet. Med. Anim. Health., 4(3), 36-41. 
Geremew Haile et al.,

Thrusfield, M., 2005. Veterinary epidemiology, 3rd edn, UK, Blackwell Science Ltd, pp 233-250.

Uilenberg, G., 1998. A field guide for the diagnosis, treatment and prevention of African animal trypanosomosis, FAO, Rome.

Zecharias, A. and Zeryehun, T., 2012. Prevalence of bovine trypanosomosis in selected district of Arba Minch, SNNPR, Southern Ethiopia. Global Vet., 8(2), 168-173. 